POLITEJA

nr 1(58), 2019, s. 173-188

https://doi.org/10.12797/Politeja.16.2019.58.10

\author{
Andrzej PORĘBSKI \\ Uniwersytet Jagielloński \\ andrzej.porebski@uj.edu.pl
}

\title{
RÖSTIGRABEN - JĘZYKOWA FOSA W POPRZEK SZWAJCARII
}

\section{ABSTRACT Röstigraben - Language Moat across Switzerland}

One of the enduring characteristics of Europe is the influence of the Roman and Germanic cultures on the continent. Switzerland is a case of these cultures crisscrossing each other. Röstigraben refers to the intra-Swiss, informal Franco-German language boundary. Here I analyze the relationship between the two language groups, first from the historical perspective and, second, from the sociological and political perspectives. The main question I ask is whether or not Röstigraben, which runs from the North to the South, splits the Swiss or bonds them. I argue that the dynamics of the relations between the two groups bonds them by not exposing the differences between them.

Keywords: Switzerland, multiculturalism, Europe’s cultural history

Słowa kluczowe: Szwajcaria, wielokulturowość, europejska historia kulturowa 


\section{WPROWADZENIE}

$\mathrm{Na}$ długotrwały proces narodzin narodów europejskich, którego korzenie tkwią we wczesnym średniowieczu ${ }^{1}$, złożył się m.in. wątek kształtowania się i konfrontacji żywiołów: romańskiego i germańskiego. Ich wielorakie wzajemne oddziaływania doprowadzily z czasem do powstania granicznego pasa pomiędzy ludami pochodzenia germańskiego i romańskiego, pasa istniejącego do dzisiaj, a ciągnącego się od krajów Beneluksu (Holandia, Belgia, Luksemburg) poprzez Niemcy i Francję (Alzację i część Lotaryngii), Szwajcarię i Włochy (Trydent-Górna Adyga/Tyrol Południowy). Bywa, że ów pas graniczny pokrywa się z granicami politycznymi, jak to ma miejsce pomiędzy Francją a Niemcami, ale bywa także, że przebiega on wewnątrz terytorium państwowego. Szczególnym przykładem tej drugiej sytuacji jest Szwajcaria, w której francusko-niemiecka granica językowa przebiega przez trzy kantony: Berno, Fryburg i Valais/ Wallis. Do tego trzeba dodać inne jeszcze obszary styku kultury romańskiej i germańskiej w tym kraju: Tessyn, czyli kanton włoskojęzyczny, graniczący z kantonem Uri (niemieckojęzycznym), Valais/Wallis (francusko-niemieckojęzycznym) i Gryzonią. Z kolei ostatni z wymienionych tutaj kantonów, Gryzonia, jest jedynym kantonem trójjęzycznym Konfederacji Szwajcarskiej. Status urzędowego mają tutaj trzy języki: jeden germański (niemiecki) i dwa romańskie (włoski i retoromański).

W czasach nam współczesnych istnienie tej wewnątrzszwajcarskiej granicy kulturowej było przedmiotem refleksji naukowej ${ }^{2}$ i publicystycznej ${ }^{3}$. Pojawiło się nawet nowe pojęcie, Röstigraben, stanowiące swego rodzaju emblemat w dyskursie społecznym. Myliłby się jednak bardzo ten, kto próbowałby interpretować kulturową granicę przecinającą Szwajcarię z północy na południe, owo Röstigraben, jedynie w kategoriach dosyć modnej dziś kultury kulinarnej. Wprawdzie przywołana nazwa Röstigraben pochodzi od nazwy potrawy - Röstikartoffeln (w skrócie Rösti), czyli odsmażanych ziemniaków, ale fakt istnienia tej granicy posiada nader rozległy kontekst historyczny oraz poważne konsekwencje polityczne. Aby dokończyć wprowadzenie tytułowego terminu, dodać należy, że Rösti jest uważane za tradycyjny przysmak kuchni niemieckiej, zaś słowo Graben oznacza fosę, rów lub kanał, a więc ziemną budowlę, przeszkodę trudną do przekroczenia, rozdzielającą tereny leżące po jej obu stronach.

Trzeba także podkreślić, że odsetek niemieckojęzycznych mieszkańców Szwajcarii przewyższa pięciokrotnie odsetek mieszkańców francuskojęzycznych, a ponad dwukrotnie odsetek wszystkich grup języków romańskich razem wziętych (francuskiego,

Zob. np. B. Zientara, Świt narodów europejskich. Powstawanie świadomości narodowej na obszarze Europy pokarolinskiej, Warszawa 1985.

2 Pisali o tym m.in. U. Windisch i in., Alltagsbeziehungen zwischen Romands und Deutschschweizern. Am Beispiel der zweisprachigen Kantone Freiburg und Wallis, Bd I-II, Basel und Frankfurt am Main 1994; W. Linder, Demokracja szwajcarska. Rozwiazzywanie konfliktów w spoteczeństwie wielokulturowym, przeł. Z. Pucek, Rzeszów 1996; a także A. Porębski, Wielokulturowość Szwajcarii na rozdrożu, Kraków 2009.

3 Ch. Büchi, Röstigraben. Das Verhältnis zwischen deutscher und französischer Schweiz. Geschichte und Perspektiven, Zürich 2000. 
włoskiego i retoromańskiego). Te proporcje są dosyć stabilne i od wielu lat nie ulegają zasadniczym zmianom. Ich wielkość wpływa jednakowoż na kształt stosunków między grupami językowymi kraju. Grupy romańskojęzyczne pozostają i czują się w mniejszości.

Przeprowadzona w prezentowanym tutaj tekście analiza stawia sobie dwojaki cel. Po pierwsze, opisany zostanie pokrótce historyczny proces tworzenia się wielokulturowego społeczeństwa szwajcarskiego, począwszy od końca XIII w., czyli od momentu powołania do życia zalążka późniejszej Konfederacji Helweckiej (1291), a skończywszy na 1848 r., czyli na uchwaleniu konstytucji szwajcarskiej, która zatwierdziła ostatecznie model wielokulturowego państwa i która - wprawdzie z wieloma poprawka$\mathrm{mi}$, ale zachowanym trzonem instytucjonalnym - obowiązuje w Szwajcarii do dzisiaj. Po drugie, poprzez odwołanie się do współczesnych badań socjologicznych z przełomu XX i XXI w. poszukiwana będzie odpowiedź na pytanie, czy wewnętrzne zróżnicowanie językowe i kulturowe społeczeństwa szwajcarskiego nie stanowi zagrożenia dla jego trwania. Z tym pytaniem wiążą się kolejne: jak kształtują się relacje między grupami językowymi Szwajcarii? Są przyjazne czy wrogie, partnerskie czy konkurencyjne? Systematyczne czy incydentalne? Zinstytucjonalizowane czy nieformalne? W czym wyrażają się współcześnie różnice między grupami językowymi: francuską i niemiecką? Czy federacja podejmuje jakieś działania w związku ze zróżnicowaniem językowym kraju? I wreszcie, czy tytułowe Röstigraben, owa kulturowa fosa przecinająca Szwajcarię z północy na południe, przejawia tendencję do bycia pogłębianą czy raczej zasypywaną?

Nie bez znaczenia jest także szerszy kontekst poruszanych tutaj problemów, a mianowicie toczące się w Europie od setek lat procesy narodotwórcze. Powszechnie wiadomo, że „naród” należy do grupy pojęć tyleż często używanych, co wieloznacznych. Nie ma jak dotąd i zapewne nigdy nie będzie jednego modelu kształtowania się społeczności narodowych. Całkowicie pomijane są tutaj - skądinąd bardzo interesujące - rozważania dotyczące powstawania narodów na kontynencie azjatyckim, w obu Amerykach i w Australii. Nawet jednak ograniczając się do samej tylko Europy, wypada stwierdzić, że mamy do czynienia z co najmniej dwoma odmiennymi typami narodów, określanymi niekiedy jako naród polityczny (naród-państwo) i naród kulturowy (naród-kultura) ${ }^{4}$. Podstawowa różnica między nimi bierze się stąd, że naród może powstawać niejako „od góry”, dzięki świadomym działaniom elit politycznych, nakierowanym na homogenizację różnych grup etnicznych w ramach wspólnej struktury politycznej, ale może też rodzić się „od dołu”, jako wynik powolnego formowania się wspólnej kultury, której nosiciel (społeczność narodowa) z czasem dopiero zabiegać będzie o jej polityczne zabezpieczenie przez instytucję państwa. Szwajcaria zalicza się w tej perspektywie do typu narodów politycznych ${ }^{5}$ jakkolwiek homogenizacja kulturowa nie była tutaj narzucana przemocą i jeśli gdziekolwiek się dokonywała, to w drodze lokalnych, żywiołowych procesów społecznych. Brak silnej władzy centralnej oraz kształtowana przez wieki tradycja

R. Szul, Jezzy, naród, państwo. Język jako zjawisko polityczne, Warszawa 2009, s. 21-58.

Zob. W. Linder, Demokracja szwajcarska..., s. 261; A. Porębski, Rodowód narodu szwajcarskiego, [w:] Zrozumieć wspótczesność, red. G. Babiński, M. Kapiszewska, Kraków 2009; R. Szul, Język..., s. 236-244. 
współpracy, mozolnego wypracowywania konsensusu i dystansowania się do zewnętrznych konfliktów sprawiły, że Szwajcaria ustrzegła się kulturowej uniformizacji, zaś naród szwajcarski istnieje przede wszystkim dlatego, że sam tego chce. Należy przy tym Szwajcaria do tej szczególnej klasy narodów, które nie poddały się językowemu ujednoliceniu i które - jak np. Belgia czy Finlandia - utrzymują więcej niż jeden oficjalny język urzędowy. A zatem tytułowy problem prezentowanej tutaj analizy posiada także kontekst narodowy, zawarty w pytaniu o źródła spójności narodu szwajcarskiego i znaczenie wewnętrznych granic (sporów) o charakterze językowym.

W perspektywie metodologicznej prezentowane tutaj opracowanie powstało przede wszystkim na podstawie analizy literatury przedmiotu, ale także dzięki możliwości przeprowadzenia przez autora kilkukrotnej obserwacji, częściowo uczestniczącej, w trójjęzycznym kantonie Gryzonii w latach 1983-1984 oraz w 2008 r. Jak wspomniano wyżej, powstanie romańsko-germańskiego kulturowego pasa granicznego ma swoje korzenie w odległej historii Szwajcarii. Aby zrozumieć genezę i dzisiejsze znaczenie Röstigraben, wypada tej historii przyjrzeć się bliżej.

\section{KSZTAŁTOWANIE SIĘ WIELOJĘZYCZNEJ SZWAJCARII}

Symboliczne narodziny Szwajcarii przypadają na 1 sierpnia 1291 r., kiedy przedstawiciele trzech leśnych kantonów - Uri, Schwyz i Unterwalden - zawarli na łączce Rütli nad jeziorem Uri traktat mający umożliwić im obronę przed ekspansywnymi dążeniami Habsburgów ${ }^{6}$. Użyte zostało określenie „narodziny symboliczne”, jako że w zamyśle jego sygnatariuszy akt ten bynajmniej nie miał prowadzić do politycznego wyodrębnienia wspomnianych obszarów z monarchii habsburskiej i utworzenia nowej, autonomicznej całości. Chodziło raczej o poluzowanie gorsetu uzależnień od lokalnych feudałów, np. poprzez uzyskanie bezpośredniej zależności od cesarza. Przykładowo - kanton Uri uzyskał taki dokument, tzw. Freiheitsbrief, już w 1231 r., niewiele później - kantony Schwyz, Obwalden i Nidwalden. To dawało kantonom m.in. prawo do używania własnej flagi i pieczęci, do utrzymywania własnych oddziałów wojskowych i sądów.

Tak więc ludność zamieszkująca we wczesnym średniowieczu tzw. kantony leśne w Alpach, czyli tereny o charakterze wiejskim, a na dodatek górzystym, od wielu lat przywykła do współpracy w walce z surową przyrodą i do jej opanowywania, m.in. poprzez budowę mostów na rwących alpejskich potokach czy wykuwanie przejść w skałach. $\mathrm{Z}$ czasem umożliwiło to uruchomienie handlowych szlaków przez górskie przełęcze. Przyczyniło się to do zainicjowania połączeń handlowych pomiędzy północą a południem Europy, dając silny impuls do rozwoju gospodarczego o wymiarze ponadregionalnym czy wręcz europejskim. Równocześnie mieszkańcy alpejskich dolin zmuszeni

6 Sygnatariuszami umowy byli prawdopodobnie dwaj rycerze i trzej wolni chłopi. Zob. J. Wojtowicz, Historia Szwajcarii, Wrocław 1976, s. 40, oraz Historia Europy, red. A. Mączak, Wrocław 1997, s. 135. Niektórzy autorzy powątpiewają jednak w możliwość ustalenia zarówno danych personalnych sygnatariuszy, jak i miejsca zawarcia umowy. Zob. W. Meyer, 1291. Die Geschichte. Die Anfänge der Eidgenossenschaft, Zürich 1991, s. 9. 
zostali do wczesnego ukształtowania struktur samorządowych i solidarnej współpracy, a także do wykształcenia pewnych form własności wspólnej - łąk i lasów.

Wracając jednak do głównego wątku, należy z mocą podkreślić, że pierwsze, zasadnicze fazy w procesie narodzin szwajcarskiego narodu i państwa przebiegały w środowisku kultury niemieckojęzycznej. Nawet jeśli to stwierdzenie zawiera w sobie ewidentne uproszczenie, polegające na tym, że w XIII w. nie istniała jeszcze standardowa wersja języka niemieckiego i na interesującym nas obszarze mówiono różnymi dialektami lokalnymi, to wszystkie one należały do rodziny języków germańskich. Element romański zaczął pojawiać się w szwajcarskim procesie narodotwórczym później, bo dopiero w XIV w. Zanim do tego doszło, pierwsze skonfederowane kantony musiały bronić swojej pozycji przed Habsburgami, którzy niechętnym okiem patrzyli na pretendentów do kontrolowania alpejskich przełęczy (czyli dochodowego handlu na linii północ-południe). W 1315 r. na wzgórzu Morgarten w kantonie Zug doszło do zbrojnej konfrontacji habsburskiego rycerstwa konnego z konfederacką piechotą. Wojska habsburskie doznały dotkliwej porażki.

Ekspansja terytorialna zwycięskich kantonów nabrała teraz widocznego impetu. Pierwszym z nowych członków konfederacji została Lucerna (1332), powiązana gospodarczo z kantonami leśnymi. Tak oto doszło do powstania Vierwaldstätte, czyli związku „czterech leśnych kantonów”. Potem dołączyły cesarskie miasto Zurych (1351) oraz Glarus (1352). W skład konfederacji wszedł także kanton Zug (1352), tyle że nie dobrowolnie, lecz w wyniku podboju, a wreszcie potężne miasto-państwo Bern (1353). I właśnie pojawienie się Berna w strukturze konfederacji uważane jest za pierwszy krok w kierunku przekształcania się Szwajcarii w organizm wielojęzyczny. O ile bowiem samo Berno było kantonem niemieckojęzycznym, to od dawna utrzymywało związki z leżącymi na zachód od niego obszarami burgundzkimi. Tak więc przystąpienie Berna otworzyło konfederację na zachód, na tereny romańskojęzyczne.

Pod koniec XIV w. konfederaci jeszcze dwukrotnie stoczyli zwycięskie bitwy z wojskami habsburskimi. Najpierw doszło do bitwy pod Sempach (1386; to tam narodziła się narodowa legenda o walecznym szwajcarskim rycerzu Arnoldzie von Winkelriedzie, który ofiarowując życie, własnym ciałem rozerwał szyki przeciwnika, czym utorował konfederatom drogę do zwycięstwa), a dwa lata później pod Näfels (1388). Kolejna wiktoria szwajcarskiej piechoty znacząco posunęła ich na drodze ku uniezależnieniu się od Habsburgów.

W 1393 r. osiem kantonów uzgodniło między sobą podstawowe zasady prowadzenia wojen. Tzw. Sempacher Brief podkreślał wspólnotę jego sygnatariuszy i porządkował reguły podziału zdobyczy wojennych ${ }^{7}$. Dziesięć lat później, w 1402 r., niektóre kantony, a zwłaszcza Uri, dokonały zbrojnej wyprawy na południe, opanowując na pewien czas włoskojęzyczną Leventinę. Celem było zdobycie kontroli nad południową drogą do przełęczy św. Gottharda. Nie od razu się to powiodło, ale z czasem Leventina oraz inne tereny włoskojęzyczne stały się częścią Szwajcarii, tworząc włoskojęzyczny kanton Tessynu.

J. Wojtowicz, Historia Szwajcarii, Wrocław 1989, s. 51. 
Natomiast dla głównego wątku niniejszego tekstu kapitalne znaczenie miało wsparcie przez konfederatów dążeń kantonu Berno do ekspansji na zachód. Stopniowo Berno uzależniało od siebie znaczące miasta (Biel, Solura, Fryburg i Neuchâtel). Starcie zbrojne, czyli tzw. wojna burgundzka, rozpoczęło się w 1474 r. Toczone walki charakteryzowały się niezwykłym okrucieństwem. Szczególnie złą sławą pod tym względem cieszy się bitwa pod Murten (1476). Wprawdzie Szwajcarzy ponownie wyszli z tych walk zwycięsko, ale rada miasta Berno potępiła sposób prowadzenia wojny i traktowania przeciwnika. A co dla dalszych relacji między ludnością niemiecko- i francuskojęzyczną bardzo istotne, doszło w tym czasie do ukształtowania negatywnych stereotypów obu skonfliktowanych społeczności. Powstał mianowicie obraz Welschów, czyli ludności francuskojęzycznej, jako ludzi fałszywych, tchórzliwych i wiarołomnych. Z kolei Burgundczycy nie pozostawali dłużni, określając Szwajcarów jako głupich, nieokrzesanych wieśniaków - niemieckie psy. W każdym razie zdobyte obszary położyły fundament pod późniejszą Szwajcarię francuskojęzyczną?.

Należy jeszcze dodać, że określenie „Welsch” pochodzi od nazwy celtyckiego plemienia „Volcae”. Posługiwali się nią Rzymianie, by określić ogólnie plemiona celtyckie (stąd też nazwy takie jak Walia czy Walonia). Z czasem nazwę tę („Walhos”) przejęli Germanie dla określenia ludów łacińskich, zwłaszcza Włochów i Francuzów; np. Retoromanów w Gryzonii nazywano „Churwalch”. W Szwajcarii określenie to dosyć wcześnie zostało ograniczone do ludności francuskojęzycznej’.

W XV w., właśnie w związku z wojnami burgundzkimi, rozróżnienie na Welschów (ludność francuskojęzyczną) i Tütschów (ludność niemieckojęzyczną) zaczęło być artykułowane w kategoriach politycznych ${ }^{10}$.

W 1481 r. do Konfederacji dołączył kolejny kanton - Fryburg. Jest to o tyle znaczące dla głównego rozważanego tutaj wątku, że Fryburg był pierwszą jednostką dwujęzyczną tworzącej się stopniowo Szwajcarii. Konfederacja pozostawała wciąż z gruntu niemieckojęzyczna, tym niemniej proces jej językowego różnicowania powoli się rozwijal. Stopniowe rozszerzanie Konfederacji na obszary burgundzkie to jeden aspekt tego procesu (warto dodać, że na obszarach tych posługiwano się dialektami franko-prowansalskimi, a nie językiem używanym w sąsiedniej Francji). Drugim jego aspektem są relacje między Konfederacją a Francją. Otóż w 1453 r. Szwajcarzy zawarli pierwsze przymierze z Francją. Jego efektem był m.in. trwający 300 lat zaciąg Szwajcarów do francuskiej armii. W 1521 r. zawarto kolejną umowę dotyczącą werbunku żołnierzy szwajcarskich, podpisaną przez wszystkie kantony, z wyjątkiem Zurychu opanowanego przez Huldrycha Zwingliego. Ta umowa była odnawiana co roku, aż do $1777 \mathrm{r}$.

Na początku XVI w. doszło do konfliktu między tymi dwoma krajami w kwestii przeęęcy św. Gottharda. Wprawdzie w 1513 r. Szwajcarzy odnieśli zwycięstwo pod Novarrą, ale nie cieszyli się nim zbyt długo. Król francuski wkroczył do Lombardii

Ch. Büchi, Röstigraben..., s. 49.

9 Tamże, s. 51.

10 P.G. Marchal, Die Ursprünge der Unabhängigkeit (401-1349), [w:] Geschichte der Schweiz und der Schweizer, Basel-Frankfurt am Main 1986, s. 144-145. 
(1515). Część kantonów (Berno, Fryburg, Solura i Valais) zgodziła się za opłatą na opuszczenie Lombardii, ale inne wdały się w bitwę pod Marignano, którą przegrały. Zawarto ugodę - „wieczysty pokój” (1516), który przez prawie 300 lat stanowił podstawę do wzajemnych stosunków. Jednakże klęska spod Marignano oznaczała koniec mocarstwowej polityki Szwajcarów.

Jak już wspomniano, w stosunkach wewnętrznych Konfederacja pozostawała organizmem niemieckojęzycznym. Pod koniec XVI w. znaczące rody fryburskie zniemczały brzmienie swoich nazwisk, a miasto Fryburg było patrolowane nawet nocami pod kątem zakazu używania języka francuskiego! Oznacza to jednak, że ówczesna germanizacyjna polityka językowa musiała być mimo wszystko mało skuteczna. Tym niemniej niemiecko-francuska granica językowa przesunęla się jeszcze na zachód, aż do miasta Sion, stolicy kantonu Valais.

Nader istotnym czynnikiem wpływającym na relacje niemiecko-francuskie w Szwajcarii była reformacja. Nie wchodząc tutaj w szczegóły rozwoju tego ruchu religijno-społecznego w poszczególnych kantonach, wskazać trzeba na jego odmienność w Niemczech i Szwajcarii. Czołowi reformatorzy w tych krajach, czyli Marcin Luter i Huldrych Zwingli, podążali odmiennymi drogami i szczerze się nawzajem nie znosili. Próba pojednania, podjęta $\mathrm{z}$ inicjatywy książąt heskich, do niczego nie doprowadziła. Rozłam w obozie reformacyjnym miał poważne konsekwencje polityczne i kulturowe. Doprowadził on mianowicie do wzajemnego zbliżenia się protestantów szwajcarskich francusko- i niemieckojęzycznych oraz osłabił więzy między Szwajcarami a Niemcami. W 1566 r. powstał swoisty szwajcarski teologiczny front jedności - Helvetische Konfession. Religijne różnice między katolikami a protestantami paradoksalnie przyczyniły się do zbliżenia między Szwajcarami niemiecko- i francuskojęzycznymi. Niektórzy badacze wręcz uważają reformację za decydujący czynnik w integracji wówczas jeszcze dwujęzycznego społeczeństwa szwajcarskiego. Francuskojęzyczni Szwajcarzy, którzy przyjęli reformację (Genewa, Vaud, Neuchâtel, Jura Południowa), zbliżyli się do protestantów niemieckojęzycznych, a zarazem oddalili się od katolickiej Francji ${ }^{11}$.

Dominacja niemieckojęzycznych Szwajcarów w Konfederacji uległa osłabieniu za przyczyną rosnącej pozycji Francji. Kraj ten stał się w XVII w. europejską potęgą pod względem gospodarczym, militarnym i kulturalnym, stopniowo poszerzając swoje terytoria na południu i wschodzie (Sabaudia, Górna Alzacja, Burgundia, Strasburg). We wzajemnych stosunkach francusko-szwajcarskich język niemiecki tracił swoją pozycję; zastępował go francuski. Wspomniane wcześniej traktaty od końca XVIII w. spisywano już tylko po francusku. Moda na francuszczyznę, także w życiu codziennym (język, ubiór, tańce, meble), obejmowała nie tylko zachodnią część Szwajcarii. Patrycjat Fryburga, nie tak dawno jeszcze przymuszany do germanizacji, powracał do francuskich form swoich nazwisk. Francusko-niemiecka granica językowa przesunęła się nieco ku wschodowi.

Wspomniana wcześniej praktyka werbunku Szwajcarów do francuskiej armii miała także następstwa kulturowe. Rekruci wracający po latach służby do rodzimych

11 To dodatkowo thumaczy, dlaczego dzisiejsza Szwajcaria francuskojęzyczna nie myśli o połączeniu $\mathrm{z}$ Francją. 
kantonów przynosili ze sobą kulturę i język francuski. Szwajcarskie elity negatywnie odnosity się do tego zjawiska, ale zapobiec mu nie mogły. W XVIII w. szwajcarskie rody rządzące mówiły po francusku i były zapatrzone w absolutyzm francuskich królów z Wersalu, natomiast elity intelektualne - w idee oświeceniowe. Otwarte starcie tych dwóch idei nastąpiło w Szwajcarii w 1798 r., przyjmując drastyczną formę inwazji wojsk francuskich i wprowadzenia odgórnie nowego ustroju politycznego - Republiki Helweckiej, wzorowanej na porewolucyjnej Francji: powstało - na niedługi wprawdzie czas - scentralizowane i zuniformizowane szwajcarskie państwo narodowe ${ }^{12}$. Co jednak dla głównego wątku niniejszego tekstu ważne, Republika Helwecka postawiła otwarcie problem języka urzędowego w tym państwie. Wprawdzie - zważywszy na okoliczności wewnętrzne i zewnętrzne - pojawiły się głosy, aby jedynym językiem urzędowym był francuski, ale ostatecznie, wobec sprzeciwu ludności, pozycję tę przyznano na równi niemieckiemu i francuskiemu, choć z jednym symptomatycznym wyjątkiem: rozkazy w legionie szwajcarskim, walczącym w armii francuskiej, wydawane miały być po niemiecku.

W praktyce życia politycznego wielojęzyczność powodowała na początku spore problemy w komunikacji. Szybko okazało się, że - z wyjątkiem wykształconych elit znajomość niemieckiego wśród ludności francuskojęzycznej była znikoma, podobnie jak francuskiego wśród niemieckojęzycznej. Mimo to wielojęzyczność kraju została uszanowana i zagwarantowana ustawowo. Bieżące problemy, jak np. tłumaczenie dokumentów państwowych, starano się rozwiązywać kompromisowo.

Ten krok ku formalnemu uznaniu wielojęzyczności państwa był ważny m.in. dlatego, że pomagał osłabiać stereotypy od kilku stuleci stygmatyzujące obie grupy językowe. Warto dodać, że w tym nurcie formalizowania i umacniania wielojęzyczności Szwajcarii pojawiła się w 1798 r. idea uniwersytetu federalnego, który miat tączyć niemiecka wnikliwość z francuską elokwencją i wtoskim smakiem ${ }^{13}$, a której autorem był Filip Albert Stapfer. Idea ta nigdy nie została zrealizowana. W Szwajcarii do dziś działają tylko uniwersytety kantonalne. Istnieją natomiast dwie politechniki federalne, jedna w niemieckojęzycznym Zurychu, a druga we francuskojęzycznej Lozannie, stolicy kantonu Vaud. Jednak samo postawienie kwestii równouprawnienia kultury niemieckiej i łacińskiej jako kamienia węgielnego Konfederacji było ważne i do dzisiaj jest aktualne.

Projekt utworzenia w Szwajcarii państwa na wzór republiki francuskiej już po kilku latach okazał się fiaskiem. Nie wchodząc tutaj w szczegółową analizę pięćdziesięcioletniego okresu politycznych wstrząsów w Szwajcarii, zakończonego uchwaleniem nowej konstytucji (1848 r.), która stworzyła fundament pod nowoczesne państwo federalne, zwróćmy uwagę tylko na te wydarzenia, które miały wpływ na kształt językowej granicy francusko-niemieckiej.

Otóż w 1815 r. przyjęto kolejną konstytucję, która za język urzędowy w federacji uznawała niemiecki, co nie przeszkadzało temu, że faktyczna wielojęzyczność kraju nie

12 T. Kästli, Die Schweiz - eine Republik in Europa. Geschichte des Nationalstaats seit 1798, Zürich 1998, s. 21.

13 Ch. Büchi, Röstigraben..., s. 124. 
została zarzucona. Ponadto przyłączenie trzech nowych kantonów - Genewy, Valais i Neuchâtel - wzmocniło proporcje językowe w kraju na rzecz ludności francuskojęzycznej. Rozwiązywanie problemów językowych przekazano do kompetencji kantonów.

Dało się zauważyć wzrost poczucia przynależności Szwajcarów do jednej wspólnoty, ponad granicami kantonów, wyznań i języków. Francuskojęzyczni Szwajcarzy przestali być obywatelami drugiej kategorii. Genewa, stolica francuskojęzycznego kantonu o tej samej nazwie, umocniła swoją pozycję wielkiego miasta europejskiego, ośrodka naukowego, kulturalnego i przemysłowego.

Wspomniana konstytucja z 1848 r., której uchwalenie zakończyło okres ścierania się dwóch przeciwstawnych filozofii budowania nowego państwa szwajcarskiego - unitaryzmu i federalizmu, zawierała także art. 109, który do rangi urzędowych podnosił trzy języki: niemiecki, francuski i po raz pierwszy także włoski. W epoce wzbierających nacjonalizmów, optujących za językową uniformizacją narodów, stanowiło to chlubny wyjątek. Instytucje federalne zobowiązane zostały do komunikowania się z kantonami w językach tychże kantonów. Wszystkie oficjalne dokumenty musiały być tłumaczone na trzy języki urzędowe. To równouprawnienie nie zawsze było respektowane w praktyce. Język niemiecki, używany przez prawie $70 \%$ społeczeństwa, zajmował często uprzywilejowaną pozycję. Najsłabsze miejsce przypadło włoskiemu ${ }^{14}$.

Tak czy owak, budowanie szwajcarskiej wielojęzycznej tożsamości narodowej nie było wolne od trudności. Przede wszystkim polegała ona na tym, że nie byto tatwo być politycznie Szwajcarem, a kulturowo "Niemcem”, „Francuzem” czy „Wtochem” w epoce, w której tak wielka wage przywiązywano do tego, co narodowe. W Szwajcarii oznaczato to uczenie się wspótżycia $z$ innojezycznymi cztonkami tego samego narodu ${ }^{15}$. Przede wszystkim (ale nie tylko) problem ten ujawniał się w stosunkach między bardzo świadomą językowo mniejszością francuskojęzyczną a mniej wyczuloną w tej materii większością niemieckojęzyczną. Ów długotrwały proces wzajemnego dostosowywania się przyniósł jednak z czasem konkretne owoce.

\section{RÖSTIGRABEN: WYZWANIE CZY KLĘSKA WIELOJĘZYCZNOŚCI SZWAJCARII?}

Za symboliczny początek świadomej dyskusji na temat Röstigraben niektórzy uznają artykuł, który ukazał się w maju 1854 r. w liberalnej gazecie „Appenzeller Zeitung” w Herisau, w niemieckojęzycznym kantonie Appenzell Ausserrhoden, położonym na wschodnim krańcu Szwajcarii ${ }^{16}$. Zawarto w nim m.in. stwierdzenie, że stereotyp przeciwstawiający sobie „Welszów” i niemieckojęzycznych Szwajcarów nie jest wymysłem współczesności, lecz ma swoje głębokie korzenie w przeszłości. Posunięto się nawet do analogii odmienności rasowej czy plemiennej. „Welszowie” mieliby charakteryzować

\footnotetext{
14 A. Porębski, Wielokulturowość Szwajcarii..., s. 53.

15 U. Im Hof, Geschichte Schweiz, Stuttgart-Berlin-Köln 1991, s. 133.

16 Ch. Büchi, Röstigraben..., s. 163.
} 
się frywolnością, skłonnością do pozoranctwa, zwracaniem uwagi na to, co zewnętrzne, oraz zamiłowaniem do wina. Tymczasem ludność niemieckojęzyczna to ludzie sztywni i szablonowi, bez polotu. Co jednak najważniejsze - istnienie ou tych grup stanowi warunek wielobarwności narodu szwajcarskiego; są one sobie nawzajem potrzebne. Odpowiedzialność za ignorowanie tego stanu rzeczy spada jednak, zdaniem autora przywoływanego tutaj tekstu, na „Welszów”. To oni sprawiają, że koegzystencja francusko- i niemieckojęzycznych grup w Szwajcarii przypomina burzliwy czy wręcz dziki związek cywilny. Niemieckojęzyczni Szwajcarzy wielokrotnie ustępowali w sytuacjach napięcia, teraz kolej na drugą stronę.

Tyle pełnego emocji i dziennikarskiego uproszczenia w głosie publicysty. Natomiast warto wskazać, jak zróżnicowanie językowe przekładało się na toczone w Szwajcarii debaty polityczne i gospodarcze. Tutaj skupimy się tylko na kilku najbardziej znaczących przykładach.

W 1874 r., gdy poddano pod referendum projekt rewizji konstytucji szwajcarskiej, kantony francuskojęzyczne, w przeciwieństwie do niemieckojęzycznych, głosowały - nieskutecznie - przeciwko centralistycznemu modelowi państwa. Ducha znowelizowanej wtedy konstytucji oddaje popularny wówczas slogan: ,jeden naródjedno prawo - jedna armia”. Najistotniejsze zmiany polegały na przejęciu przez federację nadzoru nad armią, na ujednoliceniu prawa, ustabilizowaniu Sądu Związkowego z siedzibą w Lozannie, poszerzeniu kompetencji federacji w ustawodawstwie cywilnym (z czasem rozciągniętym także na karne $)^{17}$, zagwarantowaniu wolności wyznania i sumienia.

Podobne zróżnicowanie stanowisk nałożyło się na podziały językowe przy okazji debaty nad ubojem rytualnym, centralizacją sektora bankowego czy nawet drążeniem tuneli alpejskich ułatwiających przejścia na linii północ-południe. Szwajcarzy niemieckojęzyczni inaczej widzieli ich lokalizację niż francuskojęzyczni: pierwsi optowali za przełęczą Gotthard, drudzy - za Simplon. Przy okazji budowania tych tras komunikacyjnych pojawiały się głosy wyrażające z jednej strony lęk przed „welszyzacją” (Verwelschung), szczególnie w kantonie Bern, ale także kantonie Wallis (po uruchomieniu linii kolejowej Jura-Simplon), a z drugiej strony przed germanizacją (np. w kantonie Tessynu, głównie z powodu napływu niemieckojęzycznych robotników do budowy tunelu, a po jego otwarciu - z powodu napływu ludności z Niemiec na tereny włoskojęzyczne, z naruszeniem językowej zasady terytorialnej).

Wybuch I wojny światowej przyniósł kolejne poważne zagrożenie dla wewnętrznej jedności szwajcarskiego społeczeństwa i niebezpieczeństwo pogłębienia językowej „fosy” - Röstigraben. Po przeciwnych stronach frontu znalazły się wszak Niemcy i Francja, a więc państwa stanowiące kulturowe zaplecze dla dwóch najliczniejszych szwajcarskich grup językowych. Sytuację zaostrzył najpierw fakt proniemieckich sympatii generała Ulricha Willego, który został wybrany na głównodowodzącego szwajcarskiej armii, mimo sprzeciwu w kantonach francuskojęzycznych, a potem

Ogólnoszwajcarski kodeks prawa cywilnego wydany został w 1912 r., zaś kodeks prawa karnego w 1942 r.; zob. P. Stadle, Die Schweiz von der Verfassungsrevision 1874 bis zum Ersten Weltkrieg (1874-1919), [w:] H. von Greyerz i in., Geschichte der Schweiz, München 1991, s. 138. 
dodatkowo fakt pogwałcenia przez Niemców neutralności Belgii. Doszło wtedy do praktycznego zerwania kontaktów między ludnością kantonów francusko- i niemieckojęzycznych $^{18}$. Jednak zdecydowana mobilizacja szwajcarskiej elity intelektualnej zażegnała kryzys. Przykładowo znany szwajcarski poeta, Carl Spitteler, późniejszy laureat Literackiej Nagrody Nobla, wystąpił ze słynną mową - Nasz szwajcarski punkt widzenia (Unser Schweizer Standpunkt), w której wezwał ludność niemieckojęzyczną kraju do zachowania umiaru ${ }^{19}$.

Kolejnym punktem spornym pomiędzy ludnością francusko- i niemieckojęzyczną była kwestia przystąpienia do Ligi Narodów. Kantony „francuskie” były zdecydowanie za, i tak się zresztą stało.

Znaczącym przykładem zasypywania językowej „fosy” była natomiast reakcja na zagrożenie jedności Szwajcarii ze strony faszystowskich Niemiec i Włoch w latach 30. $\mathrm{XX}$ w. Podjęto wówczas różnorakie działania integracyjne, zbiorczo określane mianem duchowej obrony kraju ${ }^{20}$. Jedną z trudnych do przecenienia składowych tych działań była - zdecydowanie poparta w referendum - nowelizacja konstytucji w aspekcie językowym, dzięki czemu język retoromański uznany został za czwarty język narodowy federacji. Wprawdzie nie oznaczało to jeszcze uzyskania rangi języka urzędowego na poziomie federalnym (co nastąpiło dopiero prawie 60 lat później), ale wzmocniło pozycję elementu romańskiego w państwie i ukazało wrażliwość grupy niemieckojęzycznej na wielojęzyczność Szwajcarii. Podobną funkcję akcentowania jedności narodu ponad podziałami językowymi w obliczu zewnętrznego zagrożenia była tzw. Wystawa Krajowa Landi, zorganizowana w 1938 r. w Zurychu. Zaś w okresie II wojny światowej generałem został Henri Guisan, oficer wywodzący się z francuskojęzycznego kantonu Vaud, co zapobiegło napięciom na liniach podziałów językowych.

Po II wojnie światowej pojawiło się wiele wydarzeń zarówno ujawniających (czy wręcz pogłębiających), jak i pomniejszających językową barierę wewnątrzszwajcarską. Wskażemy tutaj na kilka z nich. Zacznijmy od procesu wyodrębniania się nowego, dwudziestego szóstego kantonu federacji, czyli Jury. Jura to obszar w większości francuskojęzyczny i katolicki, wcielony w 1815 r. przemocą do kantonu Berno - w większości niemieckojęzycznego i protestanckiego. Po długotrwałych działaniach środowisk niezadowolonych z tego stanu rzeczy i po zastosowaniu demokratycznych procedur, doszło w 1978 r. do wydzielenia części spornych terenów z kantonu Berno i utworzenia nowej jednostki - kantonu Jura. Jednak, zdaniem Ursa Altermatta, znanego szwajcarskiego historyka i politologa, język francuski okazał się niewystarczający dla ukonstytuowania nowego kantonu, wzniesiona została na nowo także stara granica wyznaniowa ${ }^{21}$.

18 J. Wojtowicz, Historia Szwajcarii, Wrocław 1989, s. 206.

19 P. Stadle, Die Schweiz von der Verfassungsrevision..., s. 145.

20 Wyczerpująco pisze o tych procesach H. Florkowska-Frančić, „Obrona duchowa kraju” w Szwajcarii przed II wojna światową. Między kultura a polityka, [w:] Wokót historii i polityki. Studia z dziejów XIX i XX wieku dedykowane Profesorowi Wojciechowi Wrzesińskiemu $w$ siedemdziesiąta rocznice urodzin, red. S. Ciesielski i in., Toruń 2004, s. 173-184.

21 U. Altermatt, Sprachregionalismus in der Schweiz im Vormarsch, [w:] Die multikulturelle Schweiz, red. M. Escher, Zürich/Chur 2003, s. 43. 
Natomiast Wolf Linder, wybitny znawca systemu politycznego Szwajcarii, uważa cały proces separacji Jury za godną pochwały rezygnację z nacjonalistycznej zasady „jeden naród, jedno państwo, jeden język"22. Tak czy owak, powstanie kantonu Jura wzmocniło pozycję i samoświadomość grupy francuskojęzycznej.

Kolejne napięcia na linii językowej związane były z debatą nad otwarciem się Szwajcarii na zewnątrz, a konkretnie nad jej przystąpieniem do ONZ i EWG. Referenda odbyte w tych sprawach (1986 i 1992) wykazały silną polaryzację społeczeństwa. Przewagę zyskali przeciwnicy członkostwa Szwajcarii w tych organizacjach.

Podobnie też podziały językowe zbiegły się ze zróżnicowaniem opinii w sprawie ograniczenia ruchu ciężarówek (Alpenschutz, referendum w 1994 r.) czy uczestniczenia szwajcarskich żołnierzy w misji ONZ, tzw. niebieskich hełmów.

Dwa lata później dobiegła końca dziesięcioletnia debata nad rewizją artykułu językowego w konstytucji. Naród przyjął proponowaną poprawkę, która podniosła język retoromański do rangi czwartego języka urzędowego całej federacji, a nie tylko kantonu Gryzonii, jak było dotychczas. Jednak już w kolejnym roku spory językowe rozgorzały na nowo, tym razem za sprawą zuryskiego kuratora oświaty, Ernsta Buschora, który złamał obowiązującą od lat zasadę pierwszeństwa języka francuskiego jako obcego w szkołach kantonów niemieckojęzycznych i wprowadził w to miejsce język angielski. Kantony francuskojęzyczne były oburzone i po ciągnących się dyskusjach przyjęto rozwiązanie kompromisowe, które jednak wyraźnie pokazuje, że język angielski posiada coraz większą siłę przyciągania, a tracą ją tradycyjne języki narodowe Szwajcarii, automatycznie oddalając się od siebie ${ }^{23}$.

Przejmującym wyrazem istnienia językowej bariery Röstigraben były niektóre komentarze do tragedii, jaka wydarzyła się w Watykanie w 1998 r., kiedy doszło do wielokrotnego morderstwa w szeregach gwardii papieskiej. Gwardzista Cédric Tornay, pochodzący z przeważająco francuskojęzycznego kantonu Valais, zabił swego dowódcę, Aloisa Estermanna, pochodzącego z niemieckojęzycznej Lucerny, i jego żonę, Gladys Meza Romero. Prasa tłumaczyła to izolacją i tęsknotą spowodowaną złym traktowaniem francuskojęzycznych podwładnych przez niemieckojęzycznych dowódców, jakkolwiek nie brakowało też zupełnie innych prób wyjaśnienia tej tragedii ${ }^{24}$.

Listę wydarzeń, które z mniejszą lub większą siłą ujawniają istnienie językowej „fosy”, można by ciągnąć jeszcze długo, choć obraz nie uległby już zapewne istotnej zmianie. Natomiast warto na koniec przyjrzeć się zinstytucjonalizowanym działaniom

22 W. Linder, Demokracja szwajcarska..., s. 111.

23 R. Coray, Die Transformation der Sprachordnung und des nationalen Imaginären, [w:] J. Widmer i in., Die Schweizer Sprachenvielfalt im öffentlichen Diskurs. Eine sozialhistorische Analyse der Transformation der Sprachenordnung von 1848 bis 2000, Berne 2004, s. 458-460.

24 A.T. Kowalewska, Zabójcza uraza, „Dziennik Polski” 6 V 1998, [online:] https://dziennikpolski24. pl/zabojcza-uraza/ar/1743230, 1 XII 2018; J. Moskwa, 500 lat u boku papieża, „Rzeczpospolita” 20 I 2006, [online:] https://papiez.wiara.pl/doc/372537.500-lat-u-boku-papieza/2, 1 XII 2018; Szymowski L., Zbrodnia za spizowa brama, [online:] https://www.pch24.pl/zbrodnia-za-spizowa-brama,43142,i.html, 18.07.2019. 
państwa szwajcarskiego w obliczu zarysowanego tutaj problemu istnienia wewnętrznych barier językowych.

Otóż w 1985 r. rząd szwajcarski (Bundesrat) zainicjował Narodowy Projekt Badawczy nr 21, zatytułowany Kulturowa różnorodność i tożsamość narodowa. W jego ramach przeprowadzono m.in. studium jakościowe w gminach kantonów Valais i Fryburg (oba są dwujęzyczne, francusko-niemieckie, ale z przewagą ludności francuskojęzycznej). W 1994 r. opublikowano zbiorczo wyniki tych badań25.

Najważniejsze rezultaty wspomnianego interdyscyplinarnego projektu badawczego, przeprowadzonego w zgodzie z paradygmatem badań jakościowych, dają się streścić w następujących punktach:

1. Jest wiele określeń na grupy językowe w Szwajcarii; niektóre z nich są neutralne, ale wiele jest obarczonych stereotypami, przesądami, konotacjami i emocjami: Deutschschweizern, Alémanique, Suisses allemands, Welschen, Romands, Rätoromanen, Tessinern ${ }^{26}$.

2. Obok tego poziomu subiektywnego istnieje też poziom obiektywny: faktyczne relacje między grupami językowymi oraz relacje wewnątrz grup językowych.

3. W gminach, gdzie przeprowadzono szczegółowe badania, atmosfera jest raczej spokojna, jednak obawy o germanizację są częściej formułowane niż obawy o romanizację.

4. Mniejszość niemieckojęzyczna na badanych obszarach wykazała w przeszłości bezprzykładnązdolność do przystosowania się do większości francuskojęzycznej.

5. Sytuacja powoli się zmienia, czego wyrazem jest fakt pielęgnowania dialektu powszechnie używanego w mowie w kantonach niemieckojęzycznych (tzw. Schwyzerdeutsch); ludność domaga się umożliwienia odbycia całej ścieżki edukacyjnej w języku niemieckim; ponadto osoby niemieckojęzyczne oczekują realizacji zasady wzajemności, piętnując słabą znajomość języka niemieckiego przez osoby francuskojęzyczne w kantonach z większością niemiecką.

6. Mniejszość niemieckojęzyczna w Valais i Fryburgu coraz mocniej określa swą tożsamość poprzez odniesienie do własnego języka. Dodatkowo pomaga jej w tym fakt pomniejszania się światowego prestiżu języka francuskiego na rzecz języka angielskiego.

7. W mentalności mieszkańców, gdy chodzi o kwestie tożsamościowe, obserwuje się przejście od logiki: „albo-albo” (tzn. albo jestem francusko-, albo niemieckojęzyczny) do logiki „zarówno” (tzn. nie wyklucza się posiadania elementów tożsamościowych związanych z więcej niż jedną grupą językową); np. fascynacja odległym światem koegzystuje z umiłowaniem lokalności; mniejszość jest coraz bardziej respektowana przez większośćc 27 .

8. Tożsamość mniejszości jest coraz silniejsza, asertywna; odchodzi się od jednostronnego dopasowywania się mniejszości do większości. W całej Szwajcarii

25 U. Windisch i in., Bd I-II.

26 Tamże, Bd I, s. 15.

27 Tamże, Bd II, s. 497-498. 
obserwuje się silniejszą tendencję do uczenia się języka francuskiego przez Szwajcarów niemieckojęzycznych niż niemieckiego przez Szwajcarów francuskojęzycznych, co jest nader symptomatyczne w sytuacji, gdy ludność niemieckojęzyczna ponad pięciokrotnie przewyższa liczebnie ludność francuskojęzyczną.

9. Język, kultura itp. stają się pretekstem do zaangażowania politycznego w miejsce tradycyjnych czynników mobilizacji (przynależność klasowa, ideologia, antynomia między prawicą a lewicą) ${ }^{28}$.

\section{PODSUMOWANIE}

Współczesna wielokulturowość Szwajcarii jest wypadkową wielowiekowego procesu historycznego i aktualnej sytuacji społeczno-politycznej. Pierwszy element kształtował się przez prawie 600 lat, co sprawia, że okrzepł zarówno w warstwie instytucjonalnej, jak i świadomościowej i nie ma dzisiaj poważnych obaw o gwałtowne zachwianie istniejącej równowagi między grupami językowymi. Konflikty między ludnością francusko- i niemieckojęzyczną w historii pojawiały się wprawdzie wielokrotnie, ale nigdy nie doprowadziły do rozpadu federacji, gdyż kantony cieszyły się wielką autonomią, mniejszości w skali kraju są często większością w swoim kantonie, a same większości też są wewnętrznie zróżnicowane. Ponadto linie różnych konfliktów przecinały się bardziej, niż nakładały (kantony miejskie / kantony wiejskie, religie, języki...).

Wracając natomiast do pytań postawionych na wstępie tego artykułu, można stwierdzić, że rosnąca świadomość tożsamości grup językowych składających się na szwajcarskie społeczeństwo, czego jedną z konsekwencji było ukształtowanie się kulturowej granicy Röstigraben, jest swoiście amortyzowana przez zespół zjawisk o charakterze formalnym i nieformalnym. Wśród tych pierwszych na czoło wysuwa się życzliwe nastawienie do wielokulturowego dziedzictwa na poziomie federacji, wyrażające się stymulowaniem kontaktów i współpracy (poczynając od struktur typu Neue Helvetische Gesellschaft czy Pro Helvetia, poprzez szeroko zakrojoną akcję „duchowej obrony kraju” w latach 30. XX w., a na rozwiązaniach konstytucyjnych kończąc) oraz inicjowaniem i finansowaniem rządowych projektów badawczych, mających na celu coraz głębsze poznanie się, w tym także diagnozowanie i rozumienie stanu wzajemnych relacji społecznych. Natomiast zjawiska nieformalne to chociażby tradycyjna szwajcarska skłonność do poszukiwania kompromisu czy zwyczaj poznawania odmiennych kulturowo pobratymców np. w postaci tzw. Welschjahr (czyli dłuższych pobytów młodzieży z kantonów niemieckojęzycznych w rodzinach po drugiej stronie Röstigraben). W konsekwencji można zaobserwować nader obiecującą tendencję, ujawnioną w przywołanych wyżej badaniach U. Windischa i jego zespołu, polegającą na większym zainteresowaniu nauką języka francuskiego wśród ludności niemieckojęzycznej niż na odwrót. Jeśli do tego dodać wysoką świadomość faktu, iż integracja przynosi więcej korzyści niż polaryzacja

28 Tamże, Bd I, s. 502. 
czy konfrontacja, to końcowa teza prezentowanych tutaj analiz, stanowiąca, że tendencja do zasypywania Röstigraben wyraźnie przeważa nad tendencją do jego pogłębiania, wydaje się ze wszech miar uzasadniona.

\section{BIBLIOGRAFIA}

Altermatt U., Sprachregionalismus in der Schweiz im Vormarsch, [w:] Die multikulturelle Schweiz, red. M. Escher, Zürich/Chur 2003.

Büchi Ch., Röstigraben. Das Verbältnis zwischen deutscher und französischer Schweiz. Geschichte und Perspektiven, Zürich 2000.

Coray R., Die Transformation der Sprachordnung und des nationalen Imaginären, [w:] J. Widmer i in., Die Schweizer Sprachenvielfalt im öffentlichen Diskurs. Eine sozialhistorische Analyse der Transformation der Sprachenordnung von 1848 bis 2000, Berne 2004.

Florkowska-Frančić H., „Obrona duchowa kraju” w Szwajcarii przed II wojna światowa. Między kultura a polityką, [w:] Wokót historii i polityki. Studia z dziejów XIX i XX wieku dedykowane Profesorowi Wojciechowi Wrzesinskiemu w siedemdziesiata rocznice urodzin, red. S. Ciesielski i in., Torun 2004.

Hof U. Im, Geschichte Schweiz, Stuttgart-Berlin-Köln 1991.

Szymowski L., Zbrodnia za spiżowa brama, [online:] https://www.pch24.pl/zbrodnia-za-spizowa-brama,43142,i.html, 18 VII 2019.

Kästli T., Die Schweiz - eine Republik in Europa. Geschichte des Nationalstaats seit 1798, Zürich 1998.

Kowalewska A.T., Zabójcza uraza, „Dziennik Polski” 6 V 1998, [online:] https://dziennikpolski24.pl/zabojcza-uraza/ar/1743230, 1 XII 2018.

Linder W., Demokracja szwajcarska. Rozwiązywanie konfliktów w spoteczeństwie wielokulturowym, przeł. Z. Pucek, Rzeszów 1996.

Marchal P.G., Die Ursprünge der Unabhängigkeit (401-1349), [w:] Geschichte der Schweiz und der Schweizer, Basel-Frankfurt am Main 1986.

Mączak A. (red.), Historia Europy, Wroctaw 1997.

Meyer W., 1291. Die Geschichte. Die Anfänge der Eidgenossenschaft, Zürich 1991.

Moskwa J., 500 lat u boku papieża, „Rzeczpospolita” 20 I 2006, [online:] https://papiez.wiara. pl/doc/372537.500-lat-u-boku-papieza/2, 1 XII 2018.

Porębski A., Rodowód narodu szwajcarskiego, [w:] Zrozumieć wspótczesność, red. G. Babiński, M. Kapiszewska, Kraków 2009.

Porębski A., Wielokulturowość Szwajcarii na rozdrożu, Kraków 2009.

Stadle P., Die Schweiz von der Verfassungsrevision 1874 bis zum Ersten Weltkrieg (1874-1919), [w:] H. von Greyerz i in., Geschichte der Schweiz, München 1991.

Szul R., Jezzyk, naród, państwo. Jezzyk jako zjawisko polityczne, Warszawa 2009.

Windisch U. i in., Alltagsbeziehungen zwischen Romands und Deutschschweizern. Am Beispiel der zweisprachigen Kantone Freiburg und Wallis, Bd I-II, Basel und Frankfurt am Main 1994.

Wojtowicz J., Historia Szwajcarii, Wrocław 1976. 
Wojtowicz J., Historia Szwajcarii, Wrocław 1989.

Zientara B., Świt narodów europejskich. Powstawanie świadomości narodowej na obszarze Europy pokarolińskiej, Warszawa 1985.

Dr hab. Andrzej PORĘBSKI - socjolog, kulturoznawca, adiunkt w Instytucie Studiów Międzykulturowych Uniwersytetu Jagiellońskiego. Główne obszary zainteresowań: mniejszości etniczne, procesy narodotwórcze, wielokulturowość, metodologia badań społecznych. Autor m.in. monografii Wielokulturowość Szwajcarii na rozdrożu, Kraków 2009. 